\title{
PENGARUH SIKAP KERJA, KOMITMEN PROFESI DAN MOTIVASI KERJA TERHADAP KINERJA PEGAWAI DI INSPEKTORAT DAERAH KABUPATEN LABUHANBATU SELATAN
}

\author{
${ }^{1}$ Lely Fitria Harahap, ${ }^{2}$ Suriadi, ${ }^{3}$ Lilis Nurhasanah, ${ }^{4}$ Herdian Ridha, ${ }^{5}$ Dwina Sri Wahyuni \\ $1,2,3,4,5$ Universitas Islam Sumatera Utara \\ ${ }^{1}$ lely.fitria@gmail.com, ${ }^{2}$ suriadi.mm@ gmail.com, ${ }^{3}$ lilis.nurhasanah@ gmail.com, ${ }^{4}$ herdian.ridha@ gmail.com, \\ 5dwina.sriwahyuni@gmail.com
}

\begin{abstract}
The problems in research what is influence of job attitude on performance. What is influence of profession commitment on performance. What is influence of job motivation on performance. What is influence of job attitude, profession commitment and job motivation on performance. The research of purposes is for know and analysis influence of job attitude on performance. For know and analysis influence of profession commitment on performance. For know and analysis influence of job motivation on performance. For know and analysis influence of job attitude, profession commitment and job motivation on performance. Samples in the research amount to 31 employees people. Data analyze technique in the research using descriptive analyze and regression analize. The results of this research explain of job attitude variable effect significant and positive on performance. Profession commitment variable effect significant and positive on performance. Job motivation variable effect significant and positive on performance. Job attitude, profession commitment and job motivation variable effect significant and positive on performance.
\end{abstract}

Keywords : Job attitude, Profession commitment, Job motivation, Performance

\begin{abstract}
ABSTRAK : Rumusan masalah dalam penelitian ini adalah apakah ada pengaruh sikap kerja terhadap kinerja. Apakah ada pengaruh komitmen profesi terhadap kinerja. Apakah ada pengaruh motivasi kerja terhadap kinerja. Apakah ada pengaruh sikap kerja, komitmen profesi dan motivasi kerja terhadap kinerja. Tujuan penelitian ini adalah untuk mengetahui dan menganalisis pengaruh sikap kerja terhadap kinerja. Untuk mengetahui dan menganalisis pengaruh komitmen profesi terhadap kinerja. Untuk mengetahui dan menganalisis pengaruh motivasi kerja terhadap kinerja. Untuk mengetahui dan menganalisis pengaruh sikap kerja, komitmen profesi dan motivasi kerja terhadap kinerja. Sampel dalam penelitian ini berjumlah 31 orang pegawai. Teknik analisis data dalam penelitian ini menggunakan analisis deskriptif dan analisis regresi linier berganda. Hasil penelitian ini menjelaskan bahwa variabel sikap kerja berpengaruh positif dan signifikan terhadap kinerja. Variabel komitmen profesi berpengaruh positif dan signifikan terhadap kinerja,. Variabel motivasi kerja berpengaruh positif dan signifikan terhadap kinerja. Variabel sikap kerja, komitmen profesi dan motivasi kerja berpengaruh positif dan signifikan terhadap kinerja
\end{abstract}

Kata kunci : Sikap Kerja, Komitmen Profesi Dan Motivasi Kerja, Kinerja

\section{Pendahuluan}

Dalam menyelenggarakan kegiatan pemerintahan saat ini, maka peranan Pegawai Negeri Sipil (PNS) dalam suatu organisasi pemerimtahan sangatlah penting. Hal ini disebabkan karena pegawai merupakan unsur aparatur negara yang melaksanakan pemerintahan dan pembangunan dalam usaha mencapai tujuan nasional. Berbagai isu aktual kesehatan di masyarakat belakangan ini, mengharuskan aparatur Inspektorat bekerja lebih optimal dalam melakukan pengaturan, bimbingan, pelayanan, dan pengawasan sesuai tugas pokok dan fungsinya. Usaha pencapaian tujuan negara menuntut suatu kerjasama antara komponen-komponen organisasi dalam hal ini Inspektorat Daerah Kabupaten Labuhanbatu Selatan, seperti: pegawai, sarana, prasarana, sistem dan hubungan dengan instansi terkait. Diantara komponen di atas maka pegawai 
merupakan salah satu penentu keberhasilan inspektorat karena pegawai yang akan melaksanakan tugas pemerintah dalam hal ini pemeriksaan dan pengawasan yaitu memfasilitasi kepentingan pemerintah, masyarakat dan instansi terkait.

Salah satu masalah yang dihadapi oleh Inspektorat Daerah Kabupaten Labuhanbatu Selatan saat ini adalah bagaimana menciptakan sumber daya manusia yang dapat menghasilkan kinerja yang optimal sehingga tujuan inspektorat dapat tercapai. Kinerja pegawai merupakan kunci utama bagi instansi agar kelangsungan hidup operasionalnya dapat terjamin. Kinerja pegawai akan menentukan kelangsungan sebuah kegiatan instansi pemerintahan. Kinerja didefinisikan perilaku yang secara langsung menghasilkan barang atau jasa, atau memberikan dukungan langsung sebagai proses yang telah ditentukan oleh organisasi.

Kinerja pegawai merupakan hasil proses yang kompleks, baik berasal dari diri pribadi pegawai (internal factor) maupun upaya strategis dari organisasi. Menurut pendapat Colquitt at.al (2009:273), kinerja adalah nilai dari seperangkat perilaku pegawai yang berkontribusi secara positif dan negatif untuk mencapai tujuan organisasi. Kinerja memiliki 3 (tiga) dimensi yaitu perilaku tugas, perilaku moral dan perilaku menantang. Perilaku tugas adalah tingkah laku pegawai yang terlibat secara langsung dalam mentransformasikan sumber organisasi dalam kebajikan, pelayanan atau produksi organisasi. Perilaku tugas meliputi tugas rutin dan tugas dalam pembaharuan. Perilaku moral adalah aktivitas dalam bentuk kesukarelaan dari pegawai ada reward atau tidak ada reward akan tetapi tetap memberikan kontribusi pada organisasi guna memperbaiki kualitas secara keseluruhan di tempat kerja.

Berdasarkan survei awal yang peneliti lakukan di Inspektorat Daerah Kabupaten Labuhanbatu Selatan dapat penulis kemukakan variabel pertama yang mempengaruhi kinerja adalah sikap kerja pegawai. Menurut Ivancevich (2007:88), sikap kerja merupakan keadaan mental yang dipelajari dan diorganisasikan melalui pengalaman, menghasilkan pengaruh spesifik pada respons seseorang terhadap orang lain, objek, dan situasi yang berhubungan. Teori Roe (2009:116), menyatakan bahwa orang mencari kesesuaian antara keyakinan dan perasaan mereka terhadap objek dan menyatakan bahwa modifikasi sikap dapat dilakukan dengan mengubah sisi perasaan atau keyakinan tersebut, teori tersebut berpendapat bahwa kognisi, afeksi dan perilaku menentukan sikap dan bahwa sikap pun pada akhirnya menentukan kognisis, afeksi dan perilaku.

Penelitian terdahulu yang menjelaskan bahwa sikap kerja berpengaruh atau tidak berpengaruh terhadap kinerja pegawai, pertama penelitian dari Noviansyah (2011) menguji tentang pengaruh sikap kerja terhadap kinerja, kepuasan kerja, dan komitmen organisasi pada 65 staf PT. Perkebunan Minanga Ogan Baturaja. Hasil penelitian menjelaskan bahwa bahwa sikap kerja memiliki pengaruh positif tetapi tidak signifikan terhadap kinerja. Kedua penelitian dari Liao (2012), menguji tentang work values, work attitudes and job performance of Green Energy Industry Employee in Taiwan pada 485 pegawai dan direktur dari 48 organisasi green energy, hasil penelitian menjelaskan bahwa sikap kerja tidak berpengaruh terhadap kinerja pegawai. Berdasarkan hasil penelitian dari Noviansyah (2011) dan Liao (2012), yang menguji pengaruh sikap kerja terhadap kinerja mempunyai hasil yang berbeda, oleh karena itu perlu kiranya dilakukan penelitian lagi untuk memperjelas hubungan kausal antara sikap kerja terhadap kinerja, terutama di Inspektorat Daerah Kabupaten Labuhanbatu Selatan.

Variabel kedua teridentifikasi mempengaruhi kinerja pegawai Inspektorat Daerah Kabupaten Labuhanbatu Selatan adalah komitmen profesi. Menurut pendapat Krietner (2011:135), mendefenisikan komitmen profesi sebagai sebuah konsep yang memiliki tiga dimensi yaitu affective, normative, dan continuance commitment. Affective commitment adalah tingkat seberapa jauh seorang pegawai secara emosional terikat, mengenal, dan terlibat dalam organisasi. Continuance commitment adalah suatu penilaian terhadap biaya yang terkait dengan meninggalkan organisasi. Normative commitment merujuk kepada tingkat seberapa jauh seseorang secara phsychological terikat untuk menjadi pegawai dari sebuah organisasi yang didasarkan kepada perasaan seperti kesetiaan, afeksi, kehangatan, kepemilikan, kebanggaan, kesenangan, kebahagian, dan lain-lain. Penelitian terdahulu yang terkait pada komitmen profesi, yaitu penelitian yang dilakukan oleh Yuwalliatin, S. (2006), dengan hasil penelitian bahwa 
komitmen profesi berpengaruh terhadap kinerja. Fenomena yang terjadi di Inspektorat Daerah Kabupaten Labuhanbatu Selatan diantaranya masih terdapat kesenjangan atas pemahaman berbagai peraturan yang berhubungan dengan penyelenggaraan administrasi pemeriksaan dan masih terdapat keterlambatan dalam proses dari hasil pemeriksaan yang dilakukan.

Variabel ketiga yang teridentifikasi mempengaruhi kinerja pegawai di Inspektorat Daerah Kabupaten Labuhanbatu Selatan adalah motivasi kerja. Siagian (2014:88) motivasi adalah daya pendorong yang mengakibatkan seseorang mau dan rela mengerahkan kemampuan dalam bentuk keahlian atau keterampilan, tenaga dan waktunya untuk menyelenggarakan berbagai kegiatan yang menjadi tanggung jawabnya dalam rangka pencapaian tujuan organisasi. Seorang yang memiliki motivasi yang rendah mereka cenderung untuk memperlihatkan upaya yang tidak maksimal dalam melaksanakan pekerjaannya, sehingga semakin tinggi motivasi yang dimiliki oleh individu sebagai pegawai maka dapat meningkatkan kinerja pegawai itu sendiri. Dengan demikian, Inspektorat Daerah Kabupaten Labuhanbatu Selatan perlu mengetahui apa yang menjadi motivasi para pegawainya, sebab faktor tersebut dapat menjadi salah satu faktor yang menentukan tinggi atau rendahnya motivasi seorang pegawai dalam melaksanakan pekerjaan.

Berdasarkan data kehadiran pegawai di Inspektorat Daerah Kabupaten Labuhanbatu Selatan 3 (tiga) bulan terakhir menunjukkan gerafik absensi yang naik, hal ini disebabkan adanya dampak covid-19 sehingga pegawai banyak bekerja di rumah dan jika masuk kantor melalui shift-shift yang telah diatur. Selain dari pada itu masih ada pegawai yang terlambat masuk kerja dan pulang sebelum jam kerja jika pada waktu masjuk shift kantor, dimana ratarata keterlambatan pegawai masuk kerja selama 3 (tiga) bulan terakhir lebih kurang sebesar 30\% dan rata-rata pegawai yang pulang sebelum jam kerja lebih kurang 35\%. Kondisi ini menunjukkan bahwa motivasi kerja pegawai Inspektorat Daerah Kabupaten Labuhanbatu Selatan masih ada permasalan, dan diperlukan solusi bersama untuk mengatasi hal ini.

\subsection{Batasan Masalah}

Berdasarkan pada uraian di atas, banyak faktor yang teridentifikasi terkait pada variabel penelitian. Oleh karena itu peneliti membatasi permasalahan dalam penelitian ini hanya pada masalah sikap kerja, komitmen profesi, motivasi kerja dan dan kinerja pegawai.

\subsection{Hioptesis}

Berdasarkan uraian teoretis, penelitian terdahulu dan kerangka konseptual yang telah dikemukakan di atas, maka dapat ditarik hipotesis penelitian ini sebagai berikut :

1) Sikap kerja berpengaruh positif dan signifikan terhadap kinerja pegawai di Inspektorat Daerah Kabupaten Labuhanbatu Selatan.

2) Komitmen profesi berpengaruh positif dan signifikan terhadap kinerja pegawai di Inspektorat Daerah Kabupaten Labuhanbatu Selatan.

3) Motivasi kerja berpengaruh positif dan signifikan terhadap kinerja pegawai di Inspektorat Daerah Kabupaten Labuhanbatu Selatan.

4) Sikap kerja, komitmen profesi dan motivasi kerja berpengaruh positif dan signifikan terhadap kinerja pegawai di Inspektorat Daerah Kabupaten Labuhanbatu Selatan.

\subsection{Tujuan Penelitian}

Tujuan dari penelitian ini adalah :

1) Untuk mengetahui dan menganalisis pengaruh sikap kerjaterhadap kinerja pegawai di Inspektorat Daerah Kabupaten Labuhanbatu Selatan.

2) Untuk mengetahui dan menganalisis pengaruh komitmen profesi terhadap kinerja pegawai di Inspektorat Daerah Kabupaten Labuhanbatu Selatan.

3) Untuk mengetahui dan menganalisis pengaruh motivasi kerja terhadap kinerja pegawai di Inspektorat Daerah Kabupaten Labuhanbatu Selatan.

4) Untuk mengetahui dan menganalisis pengaruh sikap kerja, komitmen profesi dan motivasi kerja terhadap kinerja pegawai di Inspektorat Daerah Kabupaten Labuhanbatu Selatan.

\section{Metode Penelitian}

\subsection{Populasi}

Menurut Sugiyono (2009:90), populasi adalah wilayah generasi yang terdiri dari atas objek/subjek yang mempunyai kualitas karakteristik tertentu yang disajikan oleh peneliti untuk dipelajari dan kemudian ditarik kesimpulannya. Berdasarkan defenisi tersebut, maka populasi dalam penelitian ini adalah para 
pegawai Inspektorat Daerah Kabupaten Labuhanbatu Selatan yang berjumlah 31 orang, dimana peneliti tidak disertakan sebagai populasi.

\subsection{Sampel}

Menurut Sugiyono (2009:93), sampel adalah elemen-elemen populasi yang dipilih atas dasar kemampuan mewakilinya. Untuk menjadi pedoman jika subjeknya atau populasinya kurang dari 100, maka lebih baik diambil semua sebagai sampel, sehingga penelitiannya merupakan penelitian populasi. Selanjutnya jika jumlah subjeknya atau populasinya besar atau lebih dari 100, maka dapat diambil persentasenya. Dengan teknik penarikan sampel secara total sampling, maka sampel dalam penelitian ini seluruh populasi yaitu 31 orang pegawai Inspektorat Daerah Kabupaten Labuhanbatu Selatan.

Tabel 1. Kerangka Sampel Pegawai

\begin{tabular}{|c|l|c|}
\hline No & \multicolumn{1}{|c|}{ Keterangan } & Jumlah \\
\hline 1. & Sekretariat & 5 \\
\hline 2. & Inspektur Pembantu Wilayah I & 9 \\
\hline 3. & Inspektur Pembantu Wilayah II & 9 \\
\hline 4. & $\begin{array}{l}\text { Inspektur Pembantu Wilayah } \\
\text { III }\end{array}$ & 8 \\
\hline \multicolumn{1}{|c|}{ Jumlah } & 31 \\
\hline
\end{tabular}

Sumber : Inspektorat Daerah Kabupaten Labuhanbatu Selatan, 2020

\subsection{Uji Normalitas}

Menurut Sugiyono (2014:144) pengertian dari uji normalitas adalah untuk menguji apakah nilai residual yang dihasilkan dari regresi terdistribusi secara normal atau tidak. Model regresi yang baik adalah yang memiliki nilai residual yang terdistribusi normal. Untuk mengetahui bentuk distribusi data, bisa dilakukan dengan grafik distribusi dan analisis statistik. Pengujian dengan distribusi dilakukan dengan melihat grafik histogram yang membandingkan antara dua observasi dengan distribusi yang mendekati distribusi normal. Distribusi normal akan membentuk satu garis lurus diagonal dan ploating data residual akan dibandingkan dengan garis diagonal. Jika distribusi atau residual normal, maka garis yang menggambarkan data yang sesungguhnya akan mengikuti garis diagonalnya. Uji normalitas dengan grafik dapat dilakukan dengan program SPSS dengan analisis grafik Normal Probability Plot

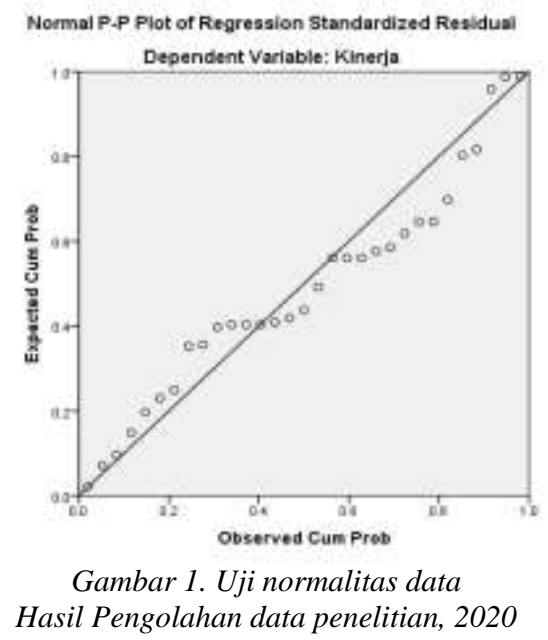

Berdasarkan gambar 1, diatas terlihat titiktitik dari ploating data residual berada di garis diagonal, hal ini dapat disimpulkan data yang diuji berdistribusi normal.

\subsection{Uji Multikolinieritas}

Salah satu asumsi dari model regresi linier bahwa tidak terjadi korelasi yang signifikan antara variabel bebasnya. Untuk menguji hal tersebut maka diperlukan suatu uji yang disebut uji multikolinieritas. Menurut Sugiyono (2014:151) pengertian multikolinieritas adalah keadaan di mana pada model regresi ditemukan adanya korelasi yang sempurna atau mendekati sempurna antar variabel independen. Pada regresi yang baik seharusnya tidak terjadi korelasi yang sempurna atau mendekati sempurna diantara variabel bebas. Uji multikolinieritas adalah untuk melihat ada atau tidaknya korelasi yang tinggi antara variabelvariabel bebasnya, maka hubungan antara variabel bebas terhadap variabel terikatnya menjadi terganggu. Jika terdapat korelasi yang kuat dimana sesama variabel independen maka konsekuensinya adalah :

a. Koefisien-koefisien regresi menjadi tidak dapat ditaksir

b. Nilai standar error setiap koefisien regresi menjadi tidak terhingga.

Dengan demikian, semakin besar korelasi diantara sesama variabel independen maka tingkat kesalahan dari koefisien regresi semakin besar yang dapat mengakibatkan standar error semakin besar pula. Cara yang digunakan untuk mendeteksi ada tidaknya multikolinieritas adalah dengan melihat besarnya nilai Variance Inflation Factor (VIF). Jika VIF dibawah 10 dan Tolerance Value diatas 0,1 maka tidak terjadi multikolinieritas. 
Tabel 2. Uji multikolinieritas

\begin{tabular}{l|c|c|}
\hline \multirow{2}{*}{ Variabel } & \multicolumn{2}{|c|}{ Collinearity Statistics } \\
\cline { 2 - 3 } & Tolerance & VIF \\
\hline Sikap kerja & 0.951 & 1.052 \\
\hline Komitmen profesi & 0.913 & 1.095 \\
\hline Motivasi kerja & 0.948 & 1.055 \\
\hline \multicolumn{2}{|c|}{ Dependent Variable $:$ Kinerja } \\
Sumber : Hasil pengolahan data, 2020
\end{tabular}

Berdasarkan Tabel 2 diatas diperoleh nilai Tolerance Value diatas 0.1 yaitu $0.951,0.913$, 0.948; hal ini menunjukan adanya korelasi yang cukup tinggi/kuat antara sesama variabel bebas dan nilai Variance Inflantion Factorrs (VIF) sebesar 1.052, 1.095, 1.055, dimana nilai VIF dari ketiga varibel bebas lebih kecil dari 10 dan dapat disimpulkan tidak terdapat multikolinieritas diantara ketiga variabel bebas yang diuji dalam penelitian ini.

\subsection{Uji Autokorelasi}

Uji autokorelasi merupakan pengujian dimana variabel dependen tidak berkorelasi dengan nilai variabel itu sendiri, baik nilai periode sebelumnya maupun nilai periode sesudahnya. Menurut Sugiyono (2014:172) pengertian dari autokorelasi adalah keadaan di mana pada model regresi ada korelasi antara residual pada periode tertentu $t$ dengan residual pada periode sebelumnya ( $\mathrm{t}-1)$, model regresi yang baik adalah yang tidak terdapat masalah autokorelasi. Metode pengujian menggunakan uji Durbin-Watson (DW-test). Salah satu ukuran dalam menentukan ada tidaknya masalah autokorelasi dengan uji Durbin-Watson (DW) dengan ketentuan sebagai berikut :

$1.65<$ DW $<2.35$ tidak terjadi autokorelasi

1.21. $<\mathrm{DW}<1.65$ atau $2.35<\mathrm{DW}<2.79$ tidak dapat disimpulkan.

DW $<1.21$ atau DW $>2.79$ terjadi autokorelasi.

Tabel 3. Uji Autokorelasi

\begin{tabular}{|l|r|r|r|r|r|r|}
\hline \multirow{4}{*}{ Model } & \multicolumn{5}{|c|}{ Change Statistics } & \multirow{2}{*}{$\begin{array}{c}\text { Durbin- } \\
\text { Watson }\end{array}$} \\
\cline { 2 - 6 } & $\begin{array}{c}\text { R Square } \\
\text { Change }\end{array}$ & F Change & df1 & df2 & $\begin{array}{c}\text { Sig. F } \\
\text { Change }\end{array}$ & \\
\hline 1 & .516 & 9.582 & 3 & 27 & .000 & 1.884 \\
\hline
\end{tabular}

Berdasarkan Tabel 3 di atas diperoleh nilai Durbin-Watson (DW) sebesar 1.884, nilai ini berada pada kisaran $1.65<\mathrm{DW}<2.35$, maka dapat disimpulkan bahwa tidak terjadi autokorelasi pada model regresi yang diuji dalam penelitian ini.

\subsection{Uji Heteroskedastisitas}

Uji heteroskedastisitas bertujuan untuk menguji apakah dalam model regresi terjadi ketidaksamaan variance dari residual satu pengamatan ke pengamatan yang lainnya. Gejala variance yang tidak sama ini disebut dengan heteroskedastisitas, sedangkan adanya gejala residual yang sama dari satu pengamatan ke pengamatan lain disebut dengan homokedastisitas. Menurut Sugiyono (2014:158) pengertian dari heteroskedastisitas adalah dimana dalam model regresi tejadi ketidaksamaan varian dari residual pada suatu pengamatan ke pengamatan yang lain. Model regresi yang baik adalah tidak terjadi heteroskedastisitas. Berbagai macam uji heteroskedastisitas yaitu dengan uji glejser, melihat pola titik-titik pada scatterplots regresi, atau uji koefisien korelasi spearman's.
Uji heteroskedastisitas dapat dilakukan dengan menggunakan grafik scatterplot antara nilai variabel terikat (ZSPRED) dengan residualnya (SRESID), dimana sumbu $X$ adalah yang diprediksi dan sumbu $\mathrm{Y}$ adalah residual. Dasar pengambilan keputusan yang dapat diambil adalah sebagai berikut :

a. Jika pola tertentu seperti titik-titik yang ada membentuk suatu pola yang teratur (bergelombang, melebar kemudian menyempit) maka telah terjadi heteroskedastisitas.

b. Jika tidak ada yang jelas serta titik-titik menyebar diatas dan dibawah angka nol pada sumbu Y maka tidak terjadi heteroskedastisitas

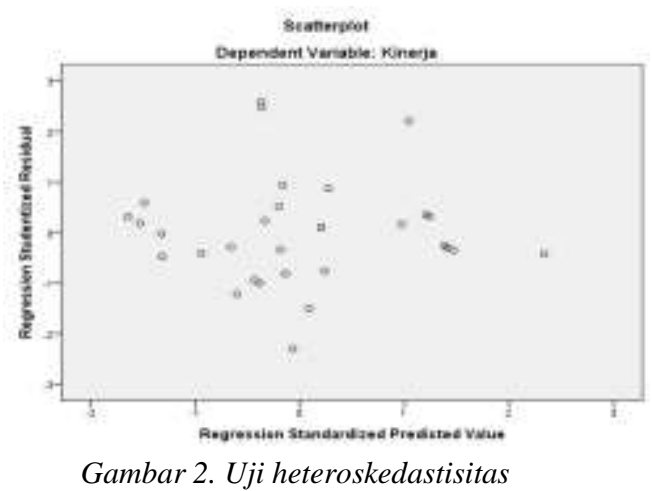


Berdasarkan gambar 2, diatas, menunjukkan titik-titik yang menyebar, sehingga dapat disimpulkan tidak terjadi heteroskedastisitas di data penelitian ini.

\section{Evaluasi dan Pembahasan}

\subsection{Hasil Analisis Regresi Linear Berganda}

Analisis regresi linier berganda dalam penelitian ini dapat dilihat dari persamaan regresinya, dan dari hasil pengolahan data diperoleh hasil berikut ini :

Tabel 4. Analisis regresi linier berganda

\begin{tabular}{|l|r|r|r|r|r|}
\hline \multirow{2}{*}{ Model } & \multicolumn{2}{|c|}{$\begin{array}{c}\text { Unstandardized } \\
\text { Coefficients }\end{array}$} & $\begin{array}{c}\text { Standardized } \\
\text { Coefficients } \\
\text { Beta }\end{array}$ & $\mathrm{t}$ & \multirow{2}{*}{ Sig. } \\
\cline { 2 - 3 } & \multicolumn{1}{|c|}{$\mathrm{B}$} & Std. Error & & \\
\hline (Constant) & -4.742 & 9.141 & & -.519 & .608 \\
\hline Sikap kerja & .529 & .158 & .461 & 3.355 & .002 \\
\hline Komitmen profesi & .273 & .128 & .300 & 2.139 & .042 \\
\hline Motivasi kerja & .325 & .151 & .295 & 2.145 & .041 \\
\hline
\end{tabular}

Sumber : Hasil pengolahan data, 2020

Berdasarkan Tabel 4, diatas dapat dibuat persamaan regresi dalam penelitian ini sebagai berikut:

$$
\begin{gathered}
Y=-4.742+0.529 X_{1}+0.273 X_{2}+ \\
0.325 X_{3}+e
\end{gathered}
$$

Dari persamaan regresi linier berganda di atas dapat dijelaskan :

1) Nilai kinerja pegawai di Inspektorat Daerah Kabupaten Labuhanbatu Selatan sebesar 4.742, dengan ketentuan nilai dari variabel bebas $\left(\mathrm{X}_{1}, \mathrm{X}_{2}\right.$, dan $\left.\mathrm{X}_{3}\right)$ diabaikan.

2) Nilai koefisien regresi $X_{1}$ (sikap kerja) mempunyai nilai positif yaitu 0.529 , hal ini menunjukkan bahwa variabel sikap kerja mempunyai pengaruh positif terhadap kinerja pegawai di Inspektorat Daerah Kabupaten Labuhanbatu Selatan.

3) Nilai koefisien regresi $X_{2}$ (komitmen profesi) mempunyai nilai positif yaitu 0.273 , hal ini menunjukkan bahwa variabel komitmen profesi mempunyai pengaruh positif terhadap kinerja pegawai di Inspektorat Daerah Kabupaten Labuhanbatu Selatan.

4) Nilai koefisien regresi $X_{3}$ (motivasi kerja) mempunyai nilai positif yaitu 0.325 , hal ini menunjukkan bahwa variabel motivasi kerja mempunyai pengaruh positif terhadap kinerja pegawai di Inspektorat Daerah Kabupaten Labuhanbatu Selatan.

\subsection{Pengaruh Sikap Kerja Terhadap Kinerja Pegawai Di Inspektorat Daerah Kabupaten Labuhanbatu Selatan.}

Untuk mengetahui pengaruh sikap kerja terhadap kinerja pegawai Inspektorat Daerah Kabupaten Labuhanbatu Selatan digunakan uji$\mathrm{t}$, sedangkan untuk melihat besarnya pengaruh digunakan nilai Beta atau Standardized Coefficient Beta.

Tabel. 5. Pengaruh sikap kerja terhadap kinerja

\begin{tabular}{|l|r|r|r|r|r|}
\hline \multirow{2}{*}{ Model } & \multicolumn{2}{|c|}{$\begin{array}{c}\text { Unstandardized } \\
\text { Coefficients }\end{array}$} & $\begin{array}{c}\text { Standardized } \\
\text { Coefficients } \\
\text { Beta }\end{array}$ & $\mathrm{t}$ & \multirow{2}{*}{ Sig. } \\
\cline { 2 - 3 } & \multicolumn{1}{|c|}{$\mathrm{B}$} & Std. Error & & & \\
\hline (Constant) & -4.742 & 9.141 & & -.519 & .608 \\
\hline Sikap kerja & .529 & .158 & .461 & 3.355 & .002 \\
\hline
\end{tabular}

a. Dependent Variable : Kinerja

Sumber : Hasil pengolahan data, 2020

Dari Tabel 5.19 diatas diperoleh nilai $\mathrm{t}_{\text {hitung }}$ sebesar 3.355. Penelitian ini menggunakan taraf signifikansi $(\alpha: 0.05)$ dan Derajat Kebebasan (DK) dengan ketentuan DK $=\mathrm{n}-2$, atau $31-2$ $=29$. Dengan ketentuan tersebut, diperoleh nilai $\mathrm{t}_{\text {tabel }}$ sebesar 2.045. Dengan kriteria hipotesis sebagai berikut :
Jika nilai $t_{\text {hitung }}>t_{\text {tabel, }}$ maka hipotesis penelitian diterima.

Jika nilai $t_{\text {hitung }}<t_{\text {tabel}}$, maka hipotesis penelitian ditolak.

Dari hasil pengolahan data diperoleh nilai $t_{\text {hitung }}>t_{\text {tabel }}(3.355>2.045)$ dan nilai signifikasi lebih kecil dari nilai $\alpha: 0.05$ yaitu $0.002<0.05$, sehingga hipotesis yang diajukan dalam 
penelitian ini diterima. Artinya variabel sikap kerja secara partial berpengaruh positif dan signifikan terhadap kinerja pegawai di Inspektorat Daerah Kabupaten Labuhanbatu Selatan. Besarnya pengaruh variabel sikap kerja terhadap kinerja pegawai di Inspektorat Daerah Kabupaten Labuhanbatu Selatan sebesar 0.461 atau $46.10 \%$. Hasil penelitian ini sejalan dengan hasil penelitian Liao (2012), yang menyatakan sikap kerja berpengaruh positif dan signifikan terhadap kinerja, akan tetapi bertentangan dengan hasil penelitian dari Noviansyah (2011). Jika pegawai mempunyai sikap kerja yang baik dalam bekerja maka akan berdampak pada peningkatan kinerja pegawai, begitu juga sebaliknya jika pegawai tidak mempunyai sikap yang baik dalam bekerja maka akan berdampak pada penurunan kinerja pegawai.

\subsection{Pengaruh Komitmen Profesi Terhadap Kinerja Pegawai Di Inspektorat Daerah Kabupaten Labuhanbatu Selatan.}

Untuk mengetahui pengaruh komitmen profesi terhadap kinerja pegawai di Inspektorat Daerah Kabupaten Labuhanbatu Selatan digunakan uji-t, sedangkan untuk melihat besarnya pengaruh digunakan nilai Beta atau Standardized Coefficient Beta.

Tabel. 6. Pengaruh komitmen profesi terhadap kinerja

\begin{tabular}{|l|r|r|r|r|r|}
\hline \multirow{2}{*}{ Model } & \multicolumn{2}{|c|}{$\begin{array}{c}\text { Unstandardized } \\
\text { Coefficients }\end{array}$} & \multirow{2}{*}{$\begin{array}{c}\text { Standardized } \\
\text { Coefficients } \\
\text { Beta }\end{array}$} & \multirow{2}{*}{$\mathrm{t}$} & \multirow{2}{*}{ Sig. } \\
\cline { 2 - 3 } & \multicolumn{1}{|c|}{$\mathrm{B}$} & \multicolumn{1}{|c|}{ Std. Error } & & \\
\hline (Constant) & -4.742 & 9.141 & & -.519 & .608 \\
\hline Komitmen profesi & .273 & .128 & .300 & 2.139 & .042 \\
\hline
\end{tabular}

a. Dependent Variable : Kinerja

Sumber : Hasil pengolahan data, 2020

Dari Tabel 6 diatas diperoleh nilai $t_{\text {hitung }}$ sebesar 2.139. Penelitian ini menggunakan taraf signifikansi $(\alpha: 0.05)$ dan Derajat Kebebasan (DK) dengan ketentuan DK $=\mathrm{n}-2$, atau $31-2$ $=29$. Dengan ketentuan tersebut, diperoleh nilai $t_{\text {tabel }}$ sebesar 2.045. Dengan kriteria hipotesis sebagai berikut :

Jika nilai $t_{\text {hitung }}>t_{\text {tabel}}$, maka hipotesis penelitian diterima.

Jika nilai $\mathrm{t}_{\text {hitung }}<\mathrm{t}_{\text {tabel}}$, maka hipotesis penelitian ditolak.

Dari hasil pengolahan data diperoleh nilai $t_{\text {hitung }}>t_{\text {tabel }}(2.139>2.045)$ dan nilai signifikasi lebih kecil dari nilai $\alpha: 0.05$ yaitu $0.042<0.05$, sehingga hipotesis yang diajukan dalam penelitian ini diterima. Artinya variabel komitmen profesi secara partial berpengaruh positif dan signifikan terhadap kinerja pegawai di Inspektorat Daerah Kabupaten Labuhanbatu Selatan. Besarnya pengaruh variabel komitmen profesi terhadap kinerja pegawai di Inspektorat Daerah Kabupaten Labuhanbatu Selatan sebesar
0.300 atau 30\%. Hasil penelitian ini sejalan dengan hasil penelitian Yuwalliatin, S. (2006), Setyaningdyah Endang, Nimran Umar Kertahadi, Thoyib Armanu (2013), Zin, R. M., (2004), yang menyatakan komitmen profesi berpengaruh positif dan signifikan terhadap kinerja. Pegawai yang mempunyai komitmen yang tinggi terhadap inspektorat maka kinerja pegawai akan meningkat, begitu juga sebaliknya jika komitmen pegawai menurun maka kinerja pegawai akan turun.

\subsection{Pengaruh Motivasi Kerja Terhadap Kinerja Pegawai Di Inspektorat Daerah Kabupaten Labuhanbatu Selatan.}

Untuk mengetahui pengaruh motivasi kerja terhadap kinerja pegawai di Inspektorat Daerah Kabupaten Labuhanbatu Selatan digunakan uji$\mathrm{t}$, sedangkan untuk melihat besarnya pengaruh digunakan nilai Beta atau Standardized Coefficient Beta.

Tabel. 7. Pengaruh motivasi kerja terhadap kinerja

\begin{tabular}{|l|r|r|r|r|r|}
\hline \multirow{2}{*}{ Model } & \multicolumn{2}{|c|}{$\begin{array}{c}\text { Unstandardized } \\
\text { Coefficients }\end{array}$} & $\begin{array}{c}\text { Standardized } \\
\text { Coefficients } \\
\text { Beta }\end{array}$ & \multirow{2}{*}{$\mathrm{t}$} & \multirow{2}{*}{ Sig. } \\
\cline { 2 - 3 } & \multicolumn{1}{|c|}{$\mathrm{B}$} & \multicolumn{1}{|c|}{ Std. Error } & & \\
\hline (Constant) & -4.742 & 9.141 & & -.519 & .608 \\
\hline Motivasi kerja & .325 & .151 & .295 & 2.145 & .041 \\
\hline
\end{tabular}

a. Dependent Variable : Kinerja

Sumber : Hasil pengolahan data, 2020 
Dari Tabel 5.21 diatas diperoleh nilai $\mathrm{t}_{\text {hitung }}$ sebesar 2.145. Penelitian ini menggunakan taraf signifikansi $(\alpha: 0.05)$ dan Derajat Kebebasan (DK) dengan ketentuan DK $=\mathrm{n}-2$, atau $31-2$ $=29$. Dengan ketentuan tersebut, diperoleh nilai $\mathrm{t}_{\text {tabel }}$ sebesar 2.045. Dengan kriteria hipotesis sebagai berikut :

Jika nilai $t_{\text {hitung }}>t_{\text {tabel}}$, maka hipotesis penelitian diterima.

Jika nilai $t_{\text {hitung }}<t_{\text {tabel}}$, maka hipotesis penelitian ditolak.

Dari hasil pengolahan data diperoleh nilai $t_{\text {hitung }}>t_{\text {tabel }}(2.145>2.045)$ dan nilai signifikasi lebih kecil dari nilai $\alpha: 0.05$ yaitu $0.041<0.05$, sehingga hipotesis yang diajukan dalam penelitian ini diterima. Artinya variabel motivasi kerja secara partial berpengaruh positif dan signifikan terhadap kinerja pegawai di Inspektorat Daerah Kabupaten Labuhanbatu Selatan. Besarnya pengaruh variabel motivasi kerja terhadap kinerja pegawai di Inspektorat
Daerah Kabupaten Labuhanbatu Selatan sebesar 0.295 atau $29.50 \%$. Hasil penelitian ini sejalan dengan hasil penelitian dari Noviansyah dan Zunaidah (2011), yang menyatakan motivasi kerja berpengaruh positif dan signifikan terhadap kinerja. Deskripsi dari hasil penelitian ini menjelaskan bahwa jika motivasi kerja pegawai sudah baik, maka kinerja pegawai akan meningkat, begitu juga sebaliknya jika motivasi kerja tidak baik maka kinerja pegawai akan menurun.

\subsection{Pengaruh Sikap Kerja, Komitmen Profesi dan Motivasi Kerja Terhadap Kinerja Pegawai Di Inspektorat Daerah Kabupaten Labuhanbatu Selatan}

Untuk mengetahui pengaruh sikap kerja, komitmen profesi dan motivasi kerja terhadap kinerja pegawai di Inspektorat Daerah Kabupaten Labuhanbatu Selatan digunakan ujiF.

Tabel 8. Pengaruh sikap kerja, komitmen profesi dan motivasi kerja terhadap kinerja

\begin{tabular}{|l|l|r|r|r|r|c|}
\hline Model & & $\begin{array}{c}\text { Sum of } \\
\text { Squares }\end{array}$ & \multicolumn{1}{c|}{$\mathrm{df}$} & $\begin{array}{c}\text { Mean } \\
\text { Square }\end{array}$ & \multicolumn{1}{c|}{$\mathrm{F}$} & \multicolumn{1}{c|}{ Sig. } \\
\hline \multirow{4}{*}{1} & Regression & 175.294 & 3 & 58.431 & 9.582 & $.000^{\mathrm{a}}$ \\
\cline { 2 - 7 } & Residual & 164.642 & 27 & 6.098 & & \\
\cline { 2 - 8 } & Total & 339.935 & 30 & & & \\
\hline
\end{tabular}

Dependent Variable : Kinerja

Sumber : Hasil pengolahan data, 2020

Dari Tabel 8 di atas diperoleh nilai $F_{\text {hitung }}$ sebesar 9.582. Penelitian ini menggunakan taraf signifikansi $(\alpha: 0.05)$ dan Derajat Kebebasan (DK) dengan ketentuan numerator : jumlah variabel -1 atau $4-1=3$, dan jumlah sampel dikurang 4 atau $31-4=27$. Dengan ketentuan tersebut, diperoleh nilai $\mathrm{F}_{\text {tabel }}$ sebesar 2.96 . Dengan kriteria pengujian hipotesis sebagai berikut :

Jika $F_{\text {hitung }}>F_{\text {tabel }}$, maka hipotesis penelitian diterima.

Jika $\mathrm{F}_{\text {hitung }}<\mathrm{F}_{\text {tabel }}$, maka hipotesis penelitian ditolak.

Dari hasil perhitungan diperoleh nilai $\mathrm{F}_{\text {hitung }}$ $>\mathrm{F}_{\text {tabel }}(9.582>2.96)$ dan nilai signifikasi 0.00 $<0.05$, sehingga hipotesis yang diajukan dalam penelitian ini diterima. Artinya variabel sikap kerja, komitmen profesi dan motivasi kerja

Tabel 9. Model summary ${ }^{b}$ pengaruh sikap kerja, komitmen profesi dan motivasi kerja terhadap kinerja

\begin{tabular}{|l|c|c|c|c|}
\hline Model & $R$ & $R$ Square & $\begin{array}{c}\text { Adjusted } R \\
\text { Square }\end{array}$ & $\begin{array}{c}\text { Std. Error of the } \\
\text { Estimate }\end{array}$ \\
\hline 1 & $.718^{\mathrm{a}}$ & .516 & .462 & 2.46938 \\
\hline Dependent Variable : Kinerja
\end{tabular}
Sumber : Hasil pengolahan data, 2020

Dependent Variable : Kinerja

Sumber : Hasil pengolahan data, 2020 secara simultan berpengaruh positif dan signifikan terhadap kinerja pegawai di Inspektorat Daerah Kabupaten Labuhanbatu Selatan. Dengan demikian model regresi ini sudah layak dan benar dan dapat disimpulkan bahwa variabel sikap kerja, komitmen profesi dan motivasi kerja mempunyai hubungan yang positif terhadap kinerja pegawai di Inspektorat Daerah Kabupaten Labuhanbatu Selatan

\subsection{Uji Determinan}

Uji determinan adalah untuk mengetahui seberapa besar pengaruh variabel sikap kerja, komitmen profesi dan motivasi kerja terhadap kinerja pegawai di Inspektorat Daerah Kabupaten Labuhanbatu Selatan, dan dapat dilihat dari model summary, khususnya nilai Adjusted Rsquare. 
Besarnya Tabel 9 diatas diperoleh nilai Adjusted Rsquare $\left(\mathrm{r}^{2}\right)$ sebesar 0.462. Nilai tersebut mempunyai maksud bahwa pengaruh variabel sikap kerja, komitmen profesi dan motivasi kerja terhadap kinerja pegawai di Inspektorat Daerah Kabupaten Labuhanbatu Selatan sebesar $46.20 \%$, sedangkan sisanya sebesar $53.80 \%$ dipengaruhi oleh faktor-faktor lain yang tidak diteliti. Dengan kata lain variabel kinerja pegawai di Inspektorat Daerah Kabupaten Labuhanbatu Selatan dapat diterangkan oleh variabel sikap kerja, komitmen profesi dan motivasi kerja sebesar $46.20 \%$, sedangkan sisanya sebesar $53.80 \%$ disebabkan oleh variabel-variabel lain yang tidak diteliti.

\section{Kesimpulan}

Berdasarkan pada pembahasan pada bab sebelumnya, maka dapat ditarik kesimpulan dari penelitian ini sebagai berikut :

1) Variabel sikap kerja secara partial berpengaruh positif dan signifikan terhadap kinerja pegawai di Inspektorat Daerah Kabupaten Labuhanbatu Selatan.

2) Variabel komitmen profesi secara partial berpengaruh positif dan signifikan terhadap kinerja pegawai di Inspektorat Daerah Kabupaten Labuhanbatu Selatan.

3) Variabel motivasi kerja secara partial berpengaruh positif dan tidak signifikan terhadap kinerja pegawai di Inspektorat Daerah Kabupaten Labuhanbatu Selatan.

4) Variabel sikap kerja, komitmen profesi dan motivasi kerja secara simultan berpengaruh positif dan signifikan terhadap kinerja pegawai di Inspektorat Daerah Kabupaten Labuhanbatu Selatan.

\section{DAFTAR PUSTAKA}

Cascio, Wayne F.,( (2006) Managing Human Resources: Productivity, Quality of Work Life, Profits, edition, New York, McGraw Hill

Colquitt, J. A., LePine, J. A., and Wesson., (2009) Organizational Behavior: Improving Performance and Commitment in the Workplace, New York, McGraw Hill, pp. 37

Cross, T.M dan Lynch. R.R. (2012). Peniliaian dan Evaluasi Kinerja: Konsep dan Praktik. Jakarta. Penerbit Ghalia Indonesia

Dhea Perdana Coenraad (2016), Pengaruh Kemampuan, Motivasi Dan Komitmen Terhadap Kinerja Pegawai, Jurnal Ekonomi, Bisnis \& Entrepreneurship Vol. 10, No. 1, April 2016, 17-34
Dessler, Gary. (2011). Manajemen Sumber Daya Manusia (Jilid I). Jakarta : Indeks.

Gibson, James L., Ivancevich, John M., Donnely, James H., and Konopaske (2009) Organizations: Behavior, Structure, Processes,New York, McGraw Hill.

Gomes, Faustino Cardoso, (2013), Manajemen Sumber Daya Manusia, Andi, Yogyakarta.

Hasibuan, Malayu S. P. (2014). Manajemen Sumber Daya Manusia. Edisi Revisi Jakarta: PT. Bumi Aksara.

Ivancevich, G., and Koropaske, D., (2011) Organizations: Behavior, Stucture, Process, Singapore, McGraw Hill Company

Liao (2012), The impact of work values, work attitudes on job performance of Green Energy Industry Employee in Taiwan

Mangkunegara, Anwar, Prabu. (2017). Evaluasi Kinerja SDM, Cetakan 4, Bandung : Refika Aditama

Mangkuprawira, S.Tb., (2011), Manajemen Sumber Daya Manusia Strategik, Ghalia Indonesia, Bogor

Meily Margaretha (2012), Pengaruh Sikap Kerja Terhadap Kinerja Karyawan Pada PT. Duta Marga Silima Di Jakarta, Jurnal Manajemen dan Bisnis Vol. 2 No. 2 April 2012: 151-166

Moekijat, (2011), Manajemen Sumber Daya Manusia, Mandar Maju, Bandung

Murphy, S. E., and Pirozzolo, F. J., (2012) Multi Journal ple Intelligences and Leadership, New Jersey, Lawrence Erlbaum

Muslimin, Muhammad Ardi, Riana Tangking Mangesa (2011), Pengaruh Komitmen Kerja, Motivasi Kerja, Sikap Kerja Terhadap Kinerja Guru Produktif SMK Negeri di Kabupaten Bima, http://eprints.unm.ac.id/14220/1/ARTIKEL. pdf.

Noviansyah dan Zunaidah (2011). Pengaruh sikap kerja dan motivasi kerja terhadap kinerja pegawai PT. Perkebunan Minanga Ogan Baturaja. Jurnal Manajemen dan Bisnis Sriwijaya Vol.9 No.18

Peraturan Pemerintah Nomor 46 Tahun 2011 tentang Penilaian Prestasi Kerja Pegawai Negeri Sipil

Petty, Ricard E., Brinol, Pablo., dan Tormala, Zakary L., (2012) 'Thought Confidence as a Determinant of Persuasion: The Self ValidationHypothesis", Journal of Personality and Social Psychology, pp. 722734 
Prawirosentono, Suyadi. (2010), MSDM "Kebijakan Kinerja Karyawan". BPFE: Yogyakarta.

Riduwan. (2007). Skala Pengukuran VariabelVariabel Bandung : Alfabeta

Rivai, Veithzal dan Sagala, Ella Jauvani. (2014). Manajemen Sumber Daya Manusia Untuk Perusahaan : Dari Teori ke Praktek. Jakarta : PT. Rajagrafindo Persada

Robbins, Stephen P., dan Judge, Timothy A., (2011) Perilaku Organisasi, Terjemahan Edisi Dua Belas, Jakarta, Salemba Empat. (2015) Organizational Behavior, $13^{\text {th }}$ edition, New Jersey, Pearson Education, Upper Saddle River.

Samsudin, Sadili. (2011). Manajemen Sumber Daya Manusia. Bandung: CV. Pustaka Setia.

Sedarmayanti. (2014). Good Governance (Kepemerintahan Yang Baik), Bandung : Mandar Maju

Sekaran, U., dan Bougie (2010), Research Methods for Busines. A Skill Building Approach. Fifth Edition. A John Wiley and Sons, Ltd, Publication.

Setyaningdyah Endang, Nimran Umar Kertahadi, Thoyib Armanu (2013). The Effects of Human Resource Competence Oragnizational Commitment and Transactioanl Leadership On Work Discipline, Job satisfaction and Employee's Performance. Interdisciplinary Journal of Contemporary Research in Business. Volume 5, No 4

Sondang P. Siagian. (2014), Manajemen Sumber Daya Manusia. Jakarta: PT Bumi Aksara
Sink, R dan Tuttle, J.K. (2009). Evaluasi Kinerja. Jakarta: Indeks Kelompok Gramedia.

Slocum, Herriegel., (2009) "Principles of Organizational Behavior Tweith Edition". Canada South western

Stone, Raymond., (2011) Human Resource Management, Fifth Edition, Australia, John Wiley dan Sons

Sugiyono. (2009). Metode Penelitian Kuantitatif dan Kualitatif dan $\mathrm{R}$ dan D. Bandung : Alfabeta

Taghavi, Safura., Ebrahimzadeh, Fariman., Bhramzadh, Hossein Ali., dan Masoumeh, Hosseini., (2014) "A Study of the Relationship Between Quality of Worklife and Performance Effectiveness of High School Teachers in Shirvan", International Journal of Academic Research in Business and Social Sciences, Vol. 4, No. 1, ISSN : 2222-6990

Thoha, Miftah. (2001). Birokrasi Indonesia Dalam Era Globalisasi, Pusdiklat Pegawai Depdiknas, Sawangan, Bogor.

Yuliandi (2014). Influence of Competency, knowledge and Role Ambiquity on Job performance and Implication for PPAT Performance. Journal of Economics and Sustainable Development. ISSN 2222-1700, ISSN 2222-2855 (Online), Vol 5 No 17

Zin, R. M., (2004) "Perception of Professional Engineers Toward Quality of Work Life and Organizational Commitment a Case Study", Gadjah Mada InternationalJournal of Business, 6(3), 323-262 